\title{
Mutagenicity of Wastewater Extracts from Pulp and Paper Industry
}

\author{
Samira Umme Aiman, Abdul Malik* \\ Department of Agricultural Microbiology, Faculty of Agricultural Sciences, Aligarh Muslim University, Aligarh, India \\ Email: ^ab_malik30@yahoo.com
}

How to cite this paper: Aiman, S.U. and Malik, A. (2017) Mutagenicity of Wastewater Extracts from Pulp and Paper Industry. Journal of Environmental Protection, 8, 206-213.

https://doi.org/10.4236/jep.2017.82016

Received: June 16, 2015

Accepted: February 25, 2017

Published: February 28, 2017

Copyright ( $\odot 2017$ by authors and Scientific Research Publishing Inc. This work is licensed under the Creative Commons Attribution International License (CC BY 4.0).

http://creativecommons.org/licenses/by/4.0/

(c) (i) Open Access

\begin{abstract}
Wastewater samples were collected from pulp and paper mill located in Kashipur (India) and were extracted using dichloromethane (DCM), chloroform and hexane solvents (all were HPLC-grade). The extracts were assayed for their mutagenic potential using Ames Salmonella mutagenicity assay. TA98 strain was found to be the most responsive, in terms of induction factor (Mi) and slope $(\mathrm{m})$ of the initial linear dose-response curve as determined by linear regression analysis up to the increasing doses indicating the presence of frame shift mutagens in the test samples. Mutagenicity of different extracts is arranged as follows: dichloromethane extracted water samples $>$ hexane extracted water samples $>$ chloroform extracted water samples. Hexane extract exhibited maximum mutagenic index of 13.0 and induction factor (Mi) 2.48 with TA98. The order of responsiveness based on the mutagenic index and induction factor for the test samples was in the following order: TA98 > TA97a $>$ TA100 > TA102 > TA104. Our findings suggest that TA97a, TA98, TA100, TA102, TA104 were sensitive towards the wastewater extracts and showed considerable mutagenicity.
\end{abstract}

\section{Keywords}

Mutagenicity, Pulp and Paper Industry, Wastewater Extracts

\section{Introduction}

Pulp and paper industries are water intensive industry and release effluent that contain a variety of naturally occurring polymers such as poly aromatic hydrocarbon, tannins, fatty acids, resin acids, lignin and its derivatives which are known for their resistance to degradation [1]. The chemicals formed during the process of pulping, bleaching and paper making have deleterious effect on aquatic life and they ultimately bioaccumulate and biomagnify in the food chain. Several studies have reported impaired liver and reproductive dysfunction in 
fishes exposed to pulp mill effluents [2] [3]. Some xenobiotics like organochlorinated dioxins etc. which are produced during paper making have been reported for their adverse health impacts such as endocrine disruption, immunosuppression, growth retardation, thyroid dysfunction, decreased fertility, and tumour promotion [4].

Mutagenicity assays are used specifically to evaluate the mutagenic potential of environmental and industrial effluent samples. In recent times growing interest in mutagenicity caused by environmental pollutants has led to the development of several biological tests for detecting and identifying mutagens in the air, water and soil [5] [6]. The genotoxicity of the pulp and paper mill effluents was established [7] [8]. A number of reviews have been published related to the genotoxicity of the pulp and paper mill effluent and the types of assays used [9] [10]. The Ames test, a mutagenicity assay with the bacteria Salmonella typhimurium was first developed by Ames et al., (1975) [11] and then reviewed by Maron and Ames (1983) [12]. Due to its simplicity, cost effectiveness and shortterm duration, the Ames test is appropriate for evaluation of the potential genotoxicity of contaminated wastewaters and soil [13] [14]. Many researchers have evaluated mutagenicty of wastewater by Ames Salmonella assay [6] [15] [16] [17].

The study focuses on mutagenicity of wastewater extracts by Ames Salmonella Mutagenicity Assay from pulp and paper industry.

\section{Materials and Methods}

\subsection{Sample Collection}

Composite wastewater samples were collected from pulp and paper industry from Kashipur, Uttarakhand (India). The samples were composited by mixing 2 $\mathrm{L}$ of water collected at five different points to make $10 \mathrm{~L}$ composite sample.

\subsection{Liquid-Liquid Extraction}

All the effluents were extracted separately with three different organic solvents, namely dichloromethane (DCM), n-hexane and chloroform (all HPLC grade). Extraction of the effluent with a solvent was done in two parts using $500 \mathrm{ml}$ effluent, which was shaken vigorously with $25 \mathrm{ml}$ of the extraction solvent. When solvent and water layers were separated, the solvent layer was collected in a beaker. The process was repeated three times with fresh $25 \mathrm{ml}$ extraction solvent. In this way a total of 1 litre effluent per solvent was extracted. The extracted organic phase was evaporated at room temperature under reduced pressure with the help of a vacuum pump and re-dissolved in $1 \mathrm{ml}$ of DMSO. These samples were filtered through $0.45 \mu \mathrm{m}$ membrane filter before they were used for genotoxicity testing.

\subsection{Bacterial Strains Used in the Study}

The characteristic of $S$. typhimurium strains is given in Table 1. The S. typhi- 
murium strains were maintained in frozen stocks and grown as described by Maron \& Ames [12]. Each strain was tested on the basis of associated genetic markers raising it from a single colony from the master plate [12].

\subsection{Salmonella Mutagenicity Test}

The preincubation test was performed as described by Maron and Ames [12] with some modifications [18]. Five doses of each water extracts i.e. 1, 5, 10, 20 and $40 \mu \mathrm{l} /$ plate were plated in triplicate with $0.1 \mathrm{ml}$ of the bacterial culture. After incubating the test sample and bacterial culture for $30 \mathrm{~min}$ at $37^{\circ} \mathrm{C}, 2.0 \mathrm{ml}$ top agar containing traces of histidine and biotin was added and contents were poured on minimal glucose agar plates. Plates were incubated at $37^{\circ} \mathrm{C}$ for $48-72$ h. Negative and positive controls were included in each assay. The negative control plates contained bacteria and solvent (DMSO) but no test sample. Methyl methane sulphonate and sodium azide served as positive controls. The criterion used to classify the results as positive was similar to that of Vargas et al., [19]: number of revertants double the spontaneous yields accompanied by a reproducible dose-response curve.

\section{Statistical Analysis}

\subsection{Mutagenic Index}

The number of his ${ }^{+}$revertants in the sample was compared to the negative control by its mutagenic index value.

Mutagenic index $=\frac{\text { Number of } \text { his }^{+} \text {revertants induced in the sample }}{\text { Number of } \text { his }^{+} \text {revertants induced in the negative control }}$

\subsection{Mutagenic Potential (m)}

The mutagenic potential of the test samples was calculated by the initial linear

Table 1. Characteristics of Salmonella typhimurium strains.

\begin{tabular}{|c|c|c|}
\hline Strain designation & Relevant Genetic Markers & Source \\
\hline \multicolumn{3}{|c|}{ Ames Tester Strains } \\
\hline TA97a & $\begin{array}{c}\text { uvrB, hisD661, bio, rfa, R-factor } \\
\text { plasmid-pkM101, frame shift mutation at G-C site }\end{array}$ & \\
\hline TA98 & $\begin{array}{c}\text { uvrB, hisD3052, bio, rfa, R-factor } \\
\text { plasmid-pkM101 frame shift mutation at G-C site }\end{array}$ & T. Nohmi, \\
\hline TA100 & $\begin{array}{l}\text { uvrB, his } G 46, \text { bio, } r f a, \mathrm{R} \text {-factor plasmid-pkM101, } \\
\text { base pair substitution mutation at G-C site }\end{array}$ & $\begin{array}{l}\text { National Institute of } \\
\text { Hygienic Sciences, } \\
\text { Division of Genetics } \\
\text { and Mutagenesis }\end{array}$ \\
\hline TA102 & $\begin{array}{c}\text { rfa, R-factor plasmid-pkM101, multicopy plasmid } \\
\text { paQ1 containing hisG428 auxotrophic marker } \\
\text { and } \text { Tet }^{\mathrm{r}} \text {, transition mutation at A-T site }\end{array}$ & Tokyo, Japan \\
\hline TA104 & $\begin{array}{c}u v r B, \text { his } G 428, r f a, \mathrm{R}-\text { factor plasmid-pkM101, } \\
\text { transition mutation at A-T site }\end{array}$ & \\
\hline
\end{tabular}


portion of the dose-response curve with tester strains. The slope (m) was obtained by the least square regression of the initial linear portion of the curve of initial dose-response.

\subsection{Induction Factor (Mi)}

The induction factor for various test strains for wastewater extracts was evaluated as follows:

$$
\mathrm{Mi}=\operatorname{lnn}-\mathrm{c} / \mathrm{c}
$$

where $\mathrm{n}$ is the number of revertant colonies in the sample and $c$ is the number of revertants in solvent control. The induction factor was calculated to determine the difference between two samples if the sensitivity pattern based on the slope (m) was similar.

\subsection{ANOVA}

To determine the significance of the number of his ${ }^{+}$revertants in the sample as compared to the control, one-way analysis of variance (ANOVA) was done at $\mathrm{P} \leq$ 0.05

\section{Results and Discussion}

Wastewaters from pulp and paper industry have been shown largely to be accumulated with organic matter recalcitrant in nature [20]. These pollutants are mixed together and form complex coloured effluent with high chemical oxygen demand (COD), biological oxygen demand (BOD), total dissolved solid (TDS) and decreased dissolved oxygen (DO) due to inhibition in photosynthesis which seriously affects aquatic flora and fauna [21]. Moreover, these pollutants are also reported as mutagenic, carcinogenic, clastogenic and endocrinic [22].

The United States Environmental Protection Agency (USEPA) and some of its international counter-parts have classified most of the phthalic acid esters, such as diethyl phthalate, benzyl butyl phthalate, di-n-butyl phthalate and di-(2ethylhexyl) phthalate, as priority pollutants and endocrine-disrupting compounds.

Salmonella/microsome reversion assay is commonly used biological parameter for monitoring the toxicity of common effluent [23] [24]. The mutagenicity of liquid-liquid extracted wastewater samples from pulp and paper mill industry was evaluated using $S$. typhimurium strains. The reversion of $\mathcal{S}$. typhimurium strains with hexane, chloroform, acidic and basic fraction of dichloromethane extract of wastewater sample are summarized in Tables 2-5. It was found that the test extracts showed maximum response with TA98 strain. There was an increase in the reversion of tester strains with increasing doses up to $20 \mu \mathrm{l} /$ plate and declined at a dose of $40 \mu \mathrm{l} / \mathrm{plate}$. Among all the strains tested, TA98 shows maximum mutagenic index of 13.0 with hexane fraction, while basic fraction of DCM exhibited mutagenic index of 11.1 in the TA98 strain. Similarly, TA98 showed maximum response in terms of induction factor (Mi) and 
Table 2. Reversion of Salmonella tester strains in the presence of hexane extracted wastewater sample.

\begin{tabular}{cccccccccc}
\hline \multicolumn{9}{c}{ Doses $(\mu \mathrm{ll} / \mathrm{plate})$} & \multicolumn{1}{c}{ LSD } \\
Strain & Control & $\mathbf{1}$ & $\mathbf{5}$ & $\mathbf{1 0}$ & $\mathbf{2 0}$ & $\mathbf{4 0}$ & $\mathbf{M i}$ & $\mathrm{m}$ & $\mathbf{P} \leq \mathbf{0 . 0 5}$ \\
\hline TA97a & $89 \pm 6$ & $181 \pm 10(2.0)$ & $228 \pm 9(2.5)$ & $284 \pm 11(3.1)$ & $312 \pm 8(3.5)$ & $276 \pm 8(3.1)$ & 0.91 & 3.5 & 3.91 \\
TA98 & $29 \pm 4$ & $119 \pm 7(4.1)$ & $167 \pm 8(5.7)$ & $241 \pm 6(8.3)$ & $377 \pm 12(13.0)$ & $319 \pm 10(11.0)$ & 2.48 & 6.7 & 4.21 \\
TA100 & $124 \pm 7$ & $208 \pm 8(1.6)$ & $260 \pm 11(2.0)$ & $316 \pm 8(2.5)$ & $390 \pm 11(3.1)$ & $338 \pm 13(2.7)$ & 0.76 & 4.5 & 14.58 \\
TA102 & $239 \pm 10$ & $289 \pm 13(1.2)$ & $331 \pm 10(1.3)$ & $400 \pm 9(1.6)$ & $468 \pm 13(1.9)$ & $411 \pm 12(1.7)$ & -0.04 & 4.0 & 3.26 \\
TA104 & $328 \pm 12$ & $371 \pm 14(1.1)$ & $427 \pm 13(1.3)$ & $478 \pm 17(1.4)$ & $523 \pm 14(1.5)$ & $485 \pm 14(1.4)$ & -0.52 & 3.5 & 3.99 \\
\hline
\end{tabular}

Table 3. Reversion of Salmonella tester strains in the presence of chloroform extracted wastewater sample.

\begin{tabular}{|c|c|c|c|c|c|c|c|c|c|}
\hline \multicolumn{9}{|c|}{ Doses ( $\mu \mathrm{l} /$ plate) } & \multirow{2}{*}{$\begin{array}{c}\text { LSD } \\
\mathrm{P} \leq 0.05\end{array}$} \\
\hline Strain & Control & 1 & 5 & 10 & 20 & 40 & $\mathbf{M i}$ & $\mathrm{m}$ & \\
\hline TA98 & $35 \pm 5$ & $147 \pm 8(4.2)$ & $200 \pm 7(5.7)$ & $267 \pm 10(7.6)$ & $312 \pm 14(8.9)$ & $278 \pm 11(7.9)$ & 2.10 & 4.8 & 19.48 \\
\hline TA100 & $130 \pm 9$ & $178 \pm 11(1.3)$ & $243 \pm 11(1.8)$ & $330 \pm 8(2.5)$ & $371 \pm 12(2.8)$ & $339 \pm 10(2.6)$ & 0.61 & 4.7 & 10.48 \\
\hline TA102 & $241 \pm 10$ & $283 \pm 13(1.1)$ & $325 \pm 9(1.3)$ & $386 \pm 11(1.6)$ & $439 \pm 13(1.8)$ & $394 \pm 13(1.6)$ & -0.19 & 3.6 & 4.41 \\
\hline TA104 & $325 \pm 11$ & $359 \pm 1(1.1)$ & $418 \pm 12(1.2)$ & $472 \pm 16(1.4)$ & $516 \pm 16(1.5)$ & $478 \pm 16(1.4)$ & -0.53 & 2.9 & 36.13 \\
\hline
\end{tabular}

Table 4. Reversion of Salmonella tester strains in the presence of acidic fraction of dichloromethane extracted wastewater sample.

\begin{tabular}{cccccccccc}
\hline \multicolumn{9}{c}{ Doses $(\mu \mathrm{l} /$ plate $)$} & LSD \\
\hline Strain & Control & $\mathbf{1}$ & $\mathbf{5}$ & $\mathbf{1 0}$ & $\mathbf{2 0}$ & $\mathbf{4 0}$ & Mi & m & P $\leq \mathbf{0 . 0 5}$ \\
\hline TA97a & $96 \pm 7$ & $194 \pm 10(2.0)$ & $258 \pm 9(2.6)$ & $315 \pm 10(3.2)$ & $361 \pm 8(3.7)$ & $307 \pm 9(3.9)$ & 1.01 & 4.08 & 4.80 \\
TA98 & $37 \pm 4$ & $168 \pm 7(4.5)$ & $203 \pm 8(5.4)$ & $271 \pm 12(7.3)$ & $400 \pm 14(10.8)$ & $346 \pm 12(9.3)$ & 2.26 & 6.6 & 5.64 \\
TA100 & $131 \pm 9$ & $236 \pm 11(1.8)$ & $295 \pm 11(2.2)$ & $368 \pm 13(2.8)$ & $448 \pm 12(3.4)$ & $360 \pm 10(2.7)$ & 0.88 & 4.7 & 3.26 \\
TA102 & $238 \pm 10$ & $346 \pm 13(1.4)$ & $378 \pm 10(1.5)$ & $443 \pm 11(1.8)$ & $491 \pm 13(2.0)$ & $430 \pm 13(1.8)$ & 0.06 & 3.63 & 5.92 \\
TA104 & $337 \pm 15$ & $408 \pm 12(1.2)$ & $448 \pm 14(1.3)$ & $514 \pm 16(1.5)$ & $561 \pm 16(1.6)$ & $526 \pm 14(1.5)$ & -0.41 & 4.0 & 4.25 \\
\hline
\end{tabular}

Table 5. Reversion of Salmonella tester strains in the presence of basic fraction of dichloromethane extracted wastewater sample.

\begin{tabular}{|c|c|c|c|c|c|c|c|c|c|}
\hline \multicolumn{9}{|c|}{ Doses ( $\mu 1 /$ plate $)$} & \multirow{2}{*}{$\begin{array}{c}\text { LSD } \\
\mathrm{P} \leq 0.05\end{array}$} \\
\hline Strain & Control & 1 & 5 & 10 & 20 & 40 & $\mathbf{M i}$ & $\mathrm{m}$ & \\
\hline TA97a & $93 \pm 6$ & $190 \pm 11(2.0)$ & $238 \pm 11(2.5)$ & $302 \pm 11(3.2)$ & $345 \pm 10(3.7)$ & $310 \pm 9(3.3)$ & 0.99 & 4.3 & 1.22 \\
\hline TA98 & $35 \pm 3$ & $130 \pm 6(4.3)$ & $197 \pm 7(6.5)$ & $258 \pm 10(7.3)$ & $390 \pm 9(11.1)$ & $338 \pm 10(9.6)$ & 2.31 & 6.8 & 9.60 \\
\hline TA100 & $129 \pm 10$ & $215 \pm 10(1.7)$ & $265 \pm 10(2.0)$ & $336 \pm 8(2.6)$ & $400 \pm 12(3.1)$ & $347 \pm 11(2.6)$ & 0.74 & 4.6 & 3.76 \\
\hline TA102 & $241 \pm 11$ & $317 \pm 9(1.3)$ & $354 \pm 12(1.4)$ & $414 \pm 11(1.7)$ & $473 \pm 11(1.9)$ & $418 \pm 13(1.7)$ & -0.03 & 4.4 & 7.34 \\
\hline TA104 & $334 \pm 13$ & $394 \pm 13(1.1)$ & $430 \pm 15(1.2)$ & $492 \pm 14(1.4)$ & $536 \pm 13(1.6)$ & $500 \pm 15(1.4)$ & -0.50 & 3.6 & 2.91 \\
\hline
\end{tabular}

slope $(\mathrm{m})$ of the initial linear dose-response curve as determined by linear regression analysis up to the increasing doses. The order of responsiveness based on the mutagenic index and induction factor for samples was in the following order: TA98 $>$ TA97a $>$ TA100 $>$ TA102 $>$ TA104 for wastewater samples (Tables 2-5).

The response of different strains in terms of slope $(\mathrm{m})$ of the initial linear dose 
response curve was obtained by the least square regression analysis. It was found that TA98 shows maximum value of the slope followed by TA100 in all the extracts of the wastewater samples. The order of responsiveness of different strains in terms of slope for hexane extract of effluent was as under: TA98 > TA100 > TA102> TA97a > TA104 (Table 2 and Table 5), while for chloroform, acidic and basic fraction of dichloromethane extracts were as follows: TA98 > TA100 > TA97a > TA104 > TA102 (Table 3 and Table 4). Analysis shows that reversion of the strains increases significantly in comparison to the negative control with increasing doses.

Our findings suggest that TA97a, TA98, TA100, TA102, TA104 are sensitive towards the extracted samples from wastewaters and show considerable mutagenicity, these results are in agreement with the previous findings thus establishing the validity of this test system in the genotoxicity determination of complex environmental mixtures [13] [14] [25].

Effluents from pulp and paper mills are highly toxic and are a major source of aquatic pollution. More than 250 chemicals have been identified in effluents which are produced at different stages of papermaking. Their toxic nature is derived from the presence of several naturally occurring and xenobiotic compounds which are formed and released during various stages of paper making [9]. The present findings suggest that the test wastewater possess mutagenic potential which may be due to its contamination with organic compounds. Therefore the study suggests that the common practice of application of untreated wastewater to agricultural land should be strictly restricted.

\section{Conclusion}

Pulp and paper mill wastewater samples are characterized by high BOD and COD levels and are heavily contaminated with various organic compounds such as lignosulphonic acids, chlorinated hydrocarbons, chlorolignins, chlorinated resin acids, chlorinated phenols, various surfactants, plasticizers and biocides which can be suspected for mutagenic and genotoxic activity. Mutagenicity of WW samples is arranged as follows: dichloromethane extracted water samples > hexane extracted water samples $>$ chloroform extracted water samples. TA98 was found to be the most responsive strain in terms of mutagenic index, mutagenic potential and induction factor, indicating the presence of frame shift mutagens in the test samples. The evaluation of hazardous wastes and effluents by mutagenicity assay may provide data useful not only for hazard identification but also for comparative risk assessment. The effluents from the paper and pulp industries are extensively used for irrigation of agricultural field causing deleterious impacts on environment and demand the need for continuous monitoring to provide a basis for improvement.

\section{References}

[1] Kumar, V., Dhall, P., Kumar, R., Singh, Y.P. and Kumar, A. (2012) Bioremediation of Agro-Based Pulp Mill Effluent by Microbial Consortium Comprising Autoch- 
thonous Bacteria. The Scientific World Journal, 2012, Article ID: 127014. https://doi.org/10.1100/2012/127014

[2] Orrego, R., Pandelides, Z., Guchardi, J. and Holdway, D. (2010) Effects of Pulp and Paper Mill Effluent Extracts on Liver Anaerobic and Aerobic Metabolic Enzymes in Rainbow Trout. Ecotoxicology and Environment Safety, 74, 761-768.

https://doi.org/10.1016/j.ecoenv.2010.10.042

[3] Robinson, R. (1994) Endocrine Effects of Pulp Mill Effluents on Non-Target Aquatic Organisms. PhD Thesis, University of Guelph, Guelph.

[4] Mandal, P.K. (2005) Dioxin: A Review of Its Environmental Effects and Its Aryl Hydrocarbon Receptor Biology. Journal of Comparative Physiology B, 175, 221230. https://doi.org/10.1007/s00360-005-0483-3

[5] Claxton, L.D. (2014) The History, Genotoxicity, and Carcinogenicity of CarbonBased Fuels and Their Emissions: 1. Principles and Background. Mutation Research, 762, 76-107. https://doi.org/10.1016/j.mrrev.2014.07.001

[6] Haq, I., Kumar, S., Raj, A., Lohani, M. and Satyanarayana, G.N.V. (2017) Genotoxicity Assessment of Pulp and Paper Mill Effluent before and after Bacterial Degradation Using Allium cepa Test. Chemosphere, 169, 642-650.

https://doi.org/10.1016/j.chemosphere.2016.11.101

[7] Houk, V.S. (1992) The Genotoxicity of Industrial Wastes and Effluents: A Review. Mutation Research/ Reviews in Genetic Toxicology, 277, 91-138.

https://doi.org/10.1016/0165-1110(92)90001-P

[8] Claxton, L.D., Houk, V.S. and Hughes, T.J. (1998) Genotoxicity of Industrial Wastes and Effluents: A Mini Review. Mutation Research, 410, 237-243. https://doi.org/10.1016/S1383-5742(98)00008-8

[9] Ali, M. and Sreekrishnan, T.R. (2001) Aquatic Toxicity from Pulp and Paper Mill Effluents: A Review. Advances in Environmental Research, 5, 175-196. https://doi.org/10.1016/S1093-0191(00)00055-1

[10] Pokhrel, D. and Viraraghavan, T. (2004) Treatment of Pulp and Paper Mill Wastewater-A Review. Science of the Total Environment, 333, 37-58. https://doi.org/10.1016/j.scitotenv.2004.05.017

[11] Ames, B., McCann, J. and Yamasaki, E. (1975) Methods for Detecting Carcinogens and Mutagens with the Salmonella/Mammalian-Microsome Mutagenicity Test. Mutation Research, 31, 347-364. https://doi.org/10.1016/0165-1161(75)90046-1

[12] Maron, D.M. and Ames, B.N. (1983) Revised Methods for the Salmonella Mutagenicity Test. Mutation Research, 113, 173-215. https://doi.org/10.1016/0165-1161(83)90010-9

[13] Ansari, M.I. and Malik, A. (2009) Genotoxicity of Agricultural Soils in the Vicinity of Industrial Area. Mutation Research, 673, 124-132. https://doi.org/10.1016/j.mrgentox.2008.12.006

[14] Masood, F. and Malik, A. (2013) Cytotoxic and Genotoxic Potential of Tannery Waste Contaminated Soils. Science of the Total Environment, 444, 153-160. https://doi.org/10.1016/j.scitotenv.2012.11.049

[15] Balbanic, D., Filipic, M., Klemencic, A.K. and Zegura, B. (2017) Raw and Biologically Treated Paper Mill Wastewater Effluents and the Recipient Surface Waters: Cytotoxic and Genotoxic Activity and the Presence of Endocrine Disrupting Compounds. Science of the Total Environment, 574, 78-89.

https://doi.org/10.1016/j.scitotenv.2016.09.030

[16] Seppa, P.L., Huuskonen, S., Kotelevtsev, S., Mikkelson, P., Rzhen, T., Stepanova, L. and Hanninen, O. (1998) Toxicity and Mutagenicity of Waste Waters from Baikalsk 
Pulp and Paper Mill: Evaluation of Pollutant Contamination in Lake Baikal. Marine Environmental Research, 46, 273-277. https://doi.org/10.1016/S0141-1136(97)00074-3

[17] Masood, F. and Malik, A. (2013) Mutagenicity and Genotoxicity Assessment of Industrial Wastewaters. Environmental Science and Pollution Research, 20, 73867397. https://doi.org/10.1007/s11356-013-1756-0

[18] Pagano, D.A. and Zeiger, E. (1992) Conditions for Detecting the Mutagenicity of Divalent Metals in Salmonella typhimurium. Environmental and Molecular Mutagenesis, 19,136-146. https://doi.org/10.1002/em.2850190208

[19] Vargas, V.M.F., Guidobono, R.R., Jordao, C. and Henriques, J.A.P. (1995) Use of Two Short-Term Tests to Evaluate the Genotoxicity of River Water Treated with Different Concentration/Extraction Procedures. Mutation Research, 343, 31-52. https://doi.org/10.1016/0165-1218(95)90060-8

[20] Lacorte, S., Latorre, A., Barcelo, D., Rigol, A., Malmqvist, A. and Welander, T. (2003) Organic Compounds in Paper-Mill Process Waters and Effluents. Trends in Analytical Chemistry, 22, 10. https://doi.org/10.1016/S0165-9936(03)01009-4

[21] Latorre, A., Malmqvist, A., Lacorte, S., Welander, T. and Barcelo, D. (2007) Evaluation of the Treatment Efficiencies of Paper Mill Wastewaters in Terms of Organic Composition and Toxicity. Environmental Pollution, 147, 648-655. https://doi.org/10.1016/j.envpol.2006.09.015

[22] Jenkins, R.L., Wilson, E.M., Angus, R.A., Howell, W.M. and Kirk, M. (2003) Androstenedione and Progesterone in the Sediment of a River Receiving Paper Mill Effluent. Toxicological Sciences, 73, 53-59. https://doi.org/10.1093/toxsci/kfg042

[23] Rehana, Z., Malik, A. and Ahmad, M. (1995) Mutagenic Activity of the Ganges Water with Special Reference to the Pesticide Pollution in the River between Kachla and Kannauj (UP). Mutation Research, 343, 137-144. https://doi.org/10.1016/0165-1218(95)90079-9

[24] Watanabe, T., Takahashi, Y., Takahashi, T., Nukaya, H., Terao, Y., Hirayama, T. and Wakabayashi, K. (2002) Seasonal Fluctuation of the Mutagenicity of River Water in Fukui, Japan, and the Contribution of 2-Phenylbenzotriazole-Type Mutagens. Mutation Research, 519, 187-197. https://doi.org/10.1016/S1383-5718(02)00139-0

[25] Aleem, A. and Malik, A. (2005) Genotoxicity of the Yamuna River Water at Okhla (Delhi), India. Ecotoxicology and Environmental Safety, 61, 404-441. https://doi.org/10.1016/j.ecoenv.2004.09.001 
Submit or recommend next manuscript to SCIRP and we will provide best service for you:

Accepting pre-submission inquiries through Email, Facebook, LinkedIn, Twitter, etc. A wide selection of journals (inclusive of 9 subjects, more than 200 journals)

Providing 24-hour high-quality service

User-friendly online submission system

Fair and swift peer-review system

Efficient typesetting and proofreading procedure

Display of the result of downloads and visits, as well as the number of cited articles Maximum dissemination of your research work

Submit your manuscript at: http://papersubmission.scirp.org/

Or contact jep@scirp.org 